\title{
ANALISIS KETIMPANGAN PEMBANGUNAN ANTARA KABUPATEN/KOTA DI PROVINSI MALUKU
}

\author{
Jefri Tipka \\ Badan Pusat Statistik Provinsi Maluku \\ J1. Wolter Monginsidi - Passo, Ambon 97323, Indonesia \\ e-mail: jefri.tipka@bps.go.id
}

\begin{abstract}
Abstrak
Perbedaan tingkat kuantitas dan kualitas sumber daya alam yang dimiliki suatu wilayah serta perbedaan kuantitas dan kualitas infrastruktur yang dimiliki wilayah, hal inilah yang menjadi salah satu penyebab timbulnya ketimpangan atau kesenjangan antar daerah. Tingkat perbedaan pendapatan masyarakat selain berasal dari faktor internal seperti SDM (sumber daya manusia) juga disebabkan dari faktor eksternal yakni ketimpangan antar wilayah. Adapun tujuan dari penelitian ini untuk mengetahui pola dan struktur ekonomi kabupaten/kota di Provinsi Maluku, untuk mengetahui pengaruh tingkat ketimpangan pembangunan ekonomi terhadap pertumbuhan ekonomi di Provinsi Maluku, dan untuk mengetahui apakah hipotesis Kuznets tentang "U-terbalik" berlaku di Provinsi Maluku. Penelitian ini menggunakan data PDRB dari tahun 2010-2014 Tahun Dasar $2010=100$, serta jumlah penduduk tahun $2010-2014$. Teknik analisis dengan Analisis Tipologi Klassen Analisis Indeks Williamson dan Korelasi Pearson.
\end{abstract}

Kata Kunci: Indeks Williamson, ketimpangan pembangunan, kurva U-terbalik, Provinsi Maluku.

\section{ANALYSIS OF DEVELOPMENT GAPS BETWEEN REGENCIES/CITIES IN THE PROVINCE OF MALUKU}

\begin{abstract}
Differences in the level of quantity and quality of natural resources owned by a region as well as differences in the quantity and quality of infrastructure is owned by the region, it is actually one of the causes of inequality or disparity between regions. The degree of difference other than people's income comes from internal factors such as HR (human resources) is also because of the external factors that imbalances between regions. The aim of the study is to examine the pattern and economic structure of the regency/city in Maluku Province, to determine the effect of Gaps of economic development to economic growth in the province of Maluku, and to determine whether the Kuznets hypothesis about the "inverted-U" applies in Maluku province.

This study uses data the GDRP of the year 2010 - 2014 Base Year $2010=100$, as well as the total population in $\quad 2010$ - 2014. Analysis techniques with Klassen Typology Analysis, Analysis Index Williamson and Correlation Pearson.

Keywords: Development gaps, index Williamson, inverted-U curve, Province of Maluku.
\end{abstract}

\section{Pendahuluan}

Ketidakpuasan timbul akibat pengendaliaan pemerintah terhadap pengendalian pemerintah pusat terhadap pengalihan sumber daya alam di daerah serta kurangnya sensitifnya pemerintah terhadap perbedaan antar daerah. permintaan yang kuat akan pembagian kewenangan ini mumunculkan ketidakpuasan. Diperkuat oleh adanya krisis moneter dan pergolakan politik mulai tahun 1997.

Di samping itu, pemberian otonomi kepada daerah sangat perlu untuk memperbesar partisipasi masyarakat di seluruh indonesia dalam memberikan keputusan yang berdampak langsung kepada daerahnya, sebab sangat tidak realistik Pemerintah Pusat membuat keputusan mengenai pelayanan masyarakat untuk seluruh wilayah negara. Demikian juga diyakini bahwa masyarakat lokal melalui kabupaten/kota memiliki 
pengetahuan yang lebih tentang kebutuhan, kondisi dan yang diprioritaskan. Mobilisasi sumber daya lebih dimungkinkan dilakukan oleh masyarakat yang dekat dengan pengambil keputusan di tingkat lokal. Otonomi daerah, anggaran daerah menjadi pintu penting yang paling mungkin setiap daerah mendinamisir kegiatan pembangunan melalui alokasi yang tepat dalam rangka membuat strategi untuk menciptakan kebijakan yang lebih tepat dalam rangka membuat strategi untuk menciptakan kebijakan yang lebih sesuai situasi masingmasing daerah.

Pemerintah daerah tidak perlu lagi harus tergantung pada pusat dalam menentukan kebijakan publik karena daerahlah yang sebenarnya mengetahui secara pasti kebutuhannya. Keikutsertaan masyarakat dalam pembuatan kebijakan publik, membuat mereka merasa memiliki dan mau ikut bertanggung jawab terhadap pembangunan yang berlangsung. Untuk meningkatkan kesejahteraan masyarakat diperlukan pertumbuhan ekonomi yang meningkat dan distribusi pendapatan yang merata. Pertumbuhan ekonomi diukur dengan Produk Domestik Regional Bruto (PDRB) dan laju pertumbuhanya atas dasar harga konstan. Ekonomi suatu daerah dikatakan mengalami pertumbuhan yang berkembang apabila tingkat kegiatan ekonominya lebih tinggi dari pada apa yang dicapai pada masa sebelumnya.

Pertumbuhan ekonomi merupakan salah satu indikator kesejahteraan masyarakat pada suatu daerah. Apabila pertumbuhan ekonomi suatu daerah meningkat diharapkan pertumbuhan tersebut dapat dinikmati merata oleh seluruh masyarakat. Sejalan dengan Hipotesis Kuznet mengenai kurva U-terbalik, dimana pada tahap-tahap pertumbuhan awal distribusi pendapatan cenderung memburuk, namun pada tahap-tahap berikutnya hal tersebut akan membaik.

Provinsi Maluku sebagai salah satu wilayah dengan sebaran yang cukup tinggi juga mengalami ketidakmerataan dalam percepatan pembangunan antar wilayahnya. Pembangunan yang dilakukan di wilayah bertujuan tidak hanya untuk meningkatkan PDRB per kapita masyarakat, namun juga untuk mengejar ketertinggalan pertumbuhan ekonomi dibandingkan dengan wilayah lain.

Dengan demikian tujuan dari penelitian ini adalah untuk mengetahui pola struktur ekonomi Kabupaten/Kota di Provinsi Maluku; untuk mengetahui pengaruh tingkat ketimpangan pembangunan ekonomi terhadap pertumbuhan ekonomi di Provinsi Maluku; dan untuk mengetahui apakah hipotesis Kuznets tentang "U terbalik" berlaku di Provinsi Maluku.

\section{Tinjauan Pustaka}

\subsection{Analisis Tipologi Klassen}

Dalam penelitian ini pendekatan yang digunakan adalah pendekatan daerah yaitu empat daerah kuadran dibagi menurut klasifikasi daerah seperti yang ditunjukan oleh Tabel 1.

Tabel 1. Klasifikasi Tipologi Klassen Pendekatan Daerah

\begin{tabular}{|c|c|c|}
\hline Laju Pertumbuhan & $\boldsymbol{y} \boldsymbol{d i}>\boldsymbol{y} \boldsymbol{n i}(+)$ & $\boldsymbol{y} \boldsymbol{d i}$ < $\boldsymbol{y n \boldsymbol { i } ( - )}$ \\
\hline $\boldsymbol{r d i}>\boldsymbol{r n \boldsymbol { i } ( + )}$ & $\begin{array}{c}\text { (I) Daerah maju dan } \\
\text { tumbuh cepat }\end{array}$ & $\begin{array}{c}\text { (II) Daerah berkembang } \\
\text { cepat tapi tidak maju }\end{array}$ \\
\hline $\boldsymbol{r d i}<\boldsymbol{r n \boldsymbol { i } ( - )}$ & $\begin{array}{c}\text { (III) Daerah maju tapi } \\
\text { tertekan }\end{array}$ & $\begin{array}{c}\text { (IV) Daerah relatif } \\
\text { tertinggal }\end{array}$ \\
\hline
\end{tabular}

\section{Keterangan:}

$$
\begin{aligned}
& r d i=\text { laju pertumbuhan Kabupaten/Kota } \mathrm{i} \\
& r n i=\text { laju pertumbuhan total Provinsi Maluku } \\
& y d i=\text { PDRB per kapita Kabupaten/Kota } \mathrm{i} \\
& r n i=\text { PDRB per kapita Provinsi Maluku }
\end{aligned}
$$

a. Kuadran I (pertama) yakni daerah cepat maju dan cepat tumbuh (high income and high growth) adalah Kabupaten/Kota yang memiliki pertumbuhan ekonomi dan PDRB perkapita yang lebih tinggi dibanding dengan Provinsi Maluku. 
b. Kuadran II (kedua) yakni daerah berkembang cepat tapi tidak maju (high growth but low income) adalah Kabupaten/Kota yang memiliki tingkat pertumbuhan tinggi, tetapi tingkat PDRB perkapita lebih rendah dibandingkan dengan Provinsi Maluku.

c. Kuadran III (ketiga) yakni daerah maju tapi tertekan (high income but low growth) adalah Kabupaten/Kota yang memiliki PDRB perkapita lebih tinggi tetapi tingkat pertumbuhannya lebih rendah dibandingkan dengan Provinsi Maluku.

d. Kuadran IV (keempat) adalah daerah relatif tertinggal (low growth and slow income) adalah Kabupaten/Kota yang memiliki tingkat pertumbuhan ekonomi dan PDRB perkapita labih rendah dibanding dengan Provinsi Maluku.

\subsection{Analisis Indeks Williamson}

Untuk mengetahui ketimpangan antar Kabupaten/Kota yang terjadi Provinsi Maluku dapat dianalisis menggunakan indeks ketimpangan regional (regional inequality) yang dinamakan indeks williamson. Indeks ketimpangan regional ini diformulasikan sebagai berikut :

$$
I W=\frac{\sqrt{\sum\left(Y_{i}-Y\right)^{2}\left(\frac{f_{i}}{n}\right)}}{Y}
$$

Keterangan :

$$
\begin{aligned}
& Y_{i}=\text { PDRB per kapita di Kabupaten/Kota } i \\
& Y=\text { PDRB rata-rata per kapita di Provinsi Maluku } \\
& f_{i}=\text { jumlah penduduk Kabupaten/Kota } i \\
& n=\text { jumlah penduduk Provinsi Maluku }
\end{aligned}
$$

Formula Indeks Williamson menggunakan PDRB per kapita dan jumlah penduduk dimana nilai yang diperoleh antara nol dan satu $(0<W<1)$. Dengan indikator bahwa apabila angka indeks ketimpangan Williamson semakin mendekati nol maka menunjukan ketimpangan yang semakin kecil dan bila angka indeks menunjukan semakin jauh dari nol maka akan menunjukan ketimpangan yang makin lebar.

\subsection{Korelasi Pearson}

Hasil korelasi pearson dapat dilihat dari nilai signifikansi, bentuk korelasi positif atau negatif apabila hubungan 2 variabel tersebut menunjukan adanya korelasi pearson nilainya kurang atau lebih dari nol (0), apabila menunjukan tidak adanya hubungan maka niai korelasi adalah nol (0). Nilai korelasi positif berarti arah hubungan antar variabel yang satu dengan variabel yang lain adalah satu arah, dengan kata lain apabila terjadi peningkatan pertumbuhan PDRB maka peningkatan tersebut akan mempengaruhi tingkat kesenjangan pendapatan regional. Hasil dari analisis korelasi pearson ini digunakan untuk mengetahui hubungan antar Indeks Wiliamson dengan PDRB perkapita.

\subsection{Teori Kuznets tentang Kurva U-terbalik}

Simon Kusnetz yang memelopori analisis pola-pola pertumbuhan historis di negara-negara maju mengemukakan bahwa pada tahap awal berikutnya, distribusi pendapatannya cenderung memburuk, namun pada tahap berikutnya, distribusi pendapatannya akan membaik. Observasi ini dikenal secara luas sebagai konsep kurva "U-terbalik", karena perubahan longitudinal (time-series) dalam distribusi pendapatan akan menurun seiring dengan peningkatan PDRB per kapita pada tahap pembangunan selanjutnya. Kemerosotan jangka pendek dalam pertumbuhan PDRB per kapita sering mengakibatkan ketimpangan yang menajam. Hipotesis Kuznets (kurva U-terbalik) dapat dibiktikan dengan membuat PDRB perkapita dan indeks kesenjangan. Grafik tersebut merupakan hubungan antar pertumbuhan PDRB dengan indeks Entropi Theil selama periode pengamatan. Kurva U-terbalik menggambarkan kesenjangan distribusi pendapatan yang meningkat pada tahap awal pembangunan dan menurun pada tahap-tahap berikutnya. 


\section{Metodologi Penelitian}

Penelitian ini menggunakan studi kasus pada Provinsi Maluku dengan menggunakan data dari sebelas kabupaten/kota di Provinsi Maluku pada tahun 2010 - 2014 (dalam [1], [2], [3], [4], [5], dan [6]), seperti yang diberikan padaTabel 2, Tabel 3 dan Tabel 4 berikut ini.

Tabel 2. PDRB Kabupaten/Kota di Provinsi Maluku Atas Dasar Harga Berlaku Tahun 2010 - 2014 Seri 2010 = 100 (Juta Rupiah)

\begin{tabular}{lrrrrr}
\hline \multirow{2}{*}{ KABUPATEN/KOTA } & \multicolumn{5}{c}{ TAHUN } \\
\cline { 2 - 6 } & \multicolumn{1}{c}{$\mathbf{2 0 1 0}$} & $\mathbf{2 0 1 1}$ & $\mathbf{2 0 1 2}$ & $\mathbf{2 0 1 3} *$ & $\mathbf{2 0 1 4} * *$ \\
\hline Maluku Tenggara Barat & \multicolumn{1}{c}{$(2)$} & $(3)$ & $(4)$ & $(5)$ & $(5)$ \\
Maluku Tenggara & $1.166 .818,03$ & $1.355 .192,27$ & $1.569 .591,24$ & $1.803 .255,71$ & $2.076 .123,06$ \\
Maluku Tengah & $3.532 .297,12$ & $4.016 .969,03$ & $4.610 .749,76$ & $5.191 .800,02$ & $5.929 .343,28$ \\
Buru & $954.861,00$ & $1.085 .335,38$ & $1.253 .404,47$ & $1.407 .316,76$ & $1.584 .873,68$ \\
Kep. Aru & $1.348 .409,05$ & $1.542 .774,74$ & $1.810 .038,72$ & $2.082 .893,85$ & $2.375 .468,56$ \\
SeramBagian Barat & $1.191 .718,35$ & $1.374 .817,94$ & $1.576 .243,47$ & $1.783 .068,71$ & $2.024 .154,73$ \\
SeramBagianTimur & $1.319 .256,02$ & $1.723 .341,91$ & $1.963 .588,08$ & $2.143 .076,52$ & $2.444 .914,35$ \\
Maluku Barat Daya & $607.040,67$ & $700.198,76$ & $817.946,50$ & $941.938,41$ & $1.152 .228,77$ \\
Buru Selatan & $536.043,18$ & $607.380,63$ & $691.202,75$ & $790.371,81$ & $901.930,27$ \\
Ambon & $5.911 .770,17$ & $6.795 .892,08$ & $7.839 .707,29$ & $8.823 .016,26$ & $9.948 .632,74$ \\
Tual & $879.817,21$ & $1.016 .250,69$ & $1.191 .740,02$ & $1.365 .347,86$ & $1.580 .148,29$ \\
\hline \multicolumn{1}{c}{ Maluku } & $\mathbf{1 8 . 4 2 8 . 5 8 4 , 5 5}$ & $\mathbf{2 1 . 3 6 7 . 8 5 7 , 8 2}$ & $\mathbf{2 4 . 6 6 1 . 7 5 1 , 2 2}$ & $\mathbf{2 7 . 8 3 4 . 4 6 3 , 9 0}$ & $\mathbf{3 1 . 7 3 3 . 3 4 2 , 0 4}$ \\
\hline
\end{tabular}

Sumber: Badan Pusat Statistik Provinsi Maluku, PDRB 2010 - 2014

Tabel 3. PDRB Per Kapita Pada Kabupaten/Kota di Provinsi MalukuTahun 2010 - 2014 Seri 2010=100 (Juta Rupiah)

\begin{tabular}{|c|c|c|c|c|c|}
\hline \multirow{2}{*}{ KABUPATEN/KOTA } & \multicolumn{5}{|c|}{ TAHUN } \\
\hline & 2010 & 2011 & 2012 & $2013 *$ & $2014 * *$ \\
\hline (1) & (2) & (3) & (4) & (5) & (5) \\
\hline Maluku Tenggara Barat & 9,27 & 10,77 & 12,40 & 13,83 & 15,65 \\
\hline Maluku Tenggara & 12,04 & 13,93 & 16,05 & 18,39 & 21,08 \\
\hline Maluku Tengah & 9,73 & 11,01 & 12,60 & 14,14 & 16,10 \\
\hline Buru & 8,74 & 9,62 & 10,76 & 11,71 & 12,78 \\
\hline Kep. Aru & 15,93 & 17,94 & 20,70 & 23,47 & 26,40 \\
\hline SeramBagian Barat & 7,21 & 8,26 & 9,42 & 10,61 & 11,99 \\
\hline SeramBagianTimur & 13,25 & 16,99 & 19,03 & 20,43 & 22,91 \\
\hline Maluku Barat Daya & 8,55 & 9,85 & 11,43 & 13,14 & 16,00 \\
\hline Buru Selatan & 9,93 & 11,03 & 12,33 & 13,82 & 15,50 \\
\hline Ambon & 17,71 & 19,49 & 21,55 & 23,24 & 25,16 \\
\hline Tual & 15,03 & 16,86 & 19,19 & 21,32 & 23,98 \\
\hline Maluku & 11,95 & 13,60 & 15,42 & 17,09 & 19,15 \\
\hline
\end{tabular}

Sumber: Badan Pusat Statistik Provinsi Maluku, PDRB 2010 - 2014 
Tabel 4. Laju Pertumbuhan PDRB pada Kabupaten/Kota di Provinsi MalukuTahun 2011 - 2014 Seri 2011=100 (Persen)

\begin{tabular}{|c|c|c|c|c|c|}
\hline \multirow{2}{*}{ KABUPATEN/KOTA } & \multicolumn{5}{|c|}{ TAHUN } \\
\hline & 2011 & 2012 & $2013 *$ & $2014 * *$ & Rata-rata \\
\hline (1) & (2) & (3) & (4) & (5) & (6) \\
\hline Maluku Tenggara Barat & 7,16 & 7,30 & 5,15 & 6,04 & 7,16 \\
\hline Maluku Tenggara & 5,98 & 7,07 & 5,88 & 6,25 & 5,98 \\
\hline Maluku Tengah & 5,40 & 6,91 & 4,46 & 6,58 & 5,40 \\
\hline Buru & 5,44 & 5,44 & 4,42 & 6,23 & 5,44 \\
\hline Kep. Aru & 5,25 & 7,84 & 5,88 & 6,84 & 5,25 \\
\hline SeramBagian Barat & 5,87 & 6,39 & 4,55 & 6,16 & 5,87 \\
\hline SeramBagianTimur & 8,54 & 3,94 & 3,15 & 8,44 & 8,54 \\
\hline Maluku Barat Daya & 5,65 & 7,46 & 5,61 & 15,35 & 5,65 \\
\hline Buru Selatan & 4,63 & 5,20 & 5,37 & 6,28 & 4,63 \\
\hline Ambon & 7,14 & 8,33 & 6,06 & 5,96 & 7,14 \\
\hline Tual & 5,90 & 7,90 & 5,90 & 6,34 & 5,90 \\
\hline Maluku & 6,34 & 7,16 & 5,26 & 6,70 & 6,34 \\
\hline
\end{tabular}

Sumber: Badan Pusat Statistik Provinsi Maluku, PDRB 2010 - 2014 (data diolah)

\section{Hasil dan Pembahasan}

\subsection{Tipologi Klassen}

Analisis Tipologi Klassen digunakan untuk mengetahui gambaran tentang struktur pertumbuhan ekonomi daerah antar Kabupaten/Kota di Provinsi Maluku tahun 2010-2014. Berdasarkan rangkuman perhitungan Tipologi Klassen maka diperoleh klasifikasi pertumbuhan antar Kabupaten/Kota di Provinsi Maluku seperti tabel 5.

Tabel 5. Klasifikasi Pertumbuhan Ekonomi

Kabupaten/Kota di Provinsi Maluku menurut Tipologi Klassen

\begin{tabular}{|c|c|c|}
\hline Laju Pertumbuhan & $y d i>y n i(+)$ & $y d i<y n i(-)$ \\
\hline$r d i>r n i(+)$ & $\begin{array}{l}\text { (I) Daerah maju dan tumbuh } \\
\text { cepat : } \\
\text { - Kota Ambon } \\
\text { - Kota Tal } \\
\text { - Kab. Maluku Tenggara } \\
\text { - Kab. Kep. Aru }\end{array}$ & $\begin{array}{l}\text { (II) Daerah berkembang cepat } \\
\text { tapi tidak maju : } \\
\text { - Kab. Maluku Tenggara } \\
\text { Barat } \\
\text { - Kab. Maluku Barat Daya }\end{array}$ \\
\hline$r d i<r n i(-)$ & $\begin{array}{l}\text { (III) Daerah maju tapi } \\
\text { tertekan : } \\
\text { - Kab. Seram Bagian } \\
\text { Timur }\end{array}$ & $\begin{array}{l}\text { (IV) Daerah relatif tertinggal : } \\
\text { - Kab. Maluku Tengah } \\
\text { - Kab. Buru } \\
\text { - Kab. Seram Bagian Barat } \\
\text { - Kab. Buru Selatan }\end{array}$ \\
\hline
\end{tabular}

Sumber : Hasil Analsis Tipologi Klassen (data diolah) 
Tabel 5 menunjukkan klasifikasi pertumbuhan ekonomi Kabupaten/Kota di Provinsi Maluku, dapat diuraikan bahwa dari lima Kabupaten/Kota yang ada di Provinsi Maluku, dapat diklasifikasikan menjadi empat daerah:

- Daerah yang pertama yakni daerah maju dan tumbuh cepat (high income and high growth) terdiri dari empat Kabupaten/Kota diantaranya : Kota Ambon, Kota tual, Kabupatan Maluku Tenggara dan Kabupaten Kepulauan Aru.

- Daerah yang kedua yakni daerah berkembang cepat tapi tidak maju (high growth but low income) terdiri dari dua Kabupaten diantaranya : Kabupaten Maluku Tenggara Barat dan Kabupaten Maluku Barat Daya.

- Daerah yang ketiga yakni daerah maju tapi tertekan (high income but low growth) terdiri dari satu Kabupaten diantaranya : Kabupaten Seram Bagian Timur.

- Daerah yang ketiga yakni daerah relatif tertinggal (low growth and slow income) terdiri dari empat Kabupaten diantaranya : Kabupaten Maluku Tengah, Kabupaten Buru, Kabupaten Seram Bagian Barat dan Kabupaten Buru Selatan.

\subsection{Analisis Indeks Williamson}

Besar kecilnya ketimpangan PDRB Perkapita antar Kabupaten/Kota memberikan gambar tentang kondisi dan perkembangan pembangunan di Provinsi Maluku. Perkembangan pembangunan daerah wilayah Provinsi Maluku akan dibahas pemerataan PDRB per kapita antar Kabupaten/Kota yang dianalisis dengan menggunakan Indeks Williamson. Indeks Williamson merupakan koefisien persebaran dari rata-rata nilai sebaran dihitung berdasarkan estimasi dari nilai PDRB dan penduduk yang berada pada lingkup wilayah dikaji dan dianalisis, hasil analisis indeks Williamson dapat dilihat pada Tabel 6.

Tabel 6. Indeks Williamson antar Kabupaten/Kota di Provinsi MalukuTahun 2007 - 2010

\begin{tabular}{ccc}
\hline No & Tahun & Indeks Williamson \\
\hline$(1)$ & $(2)$ & $(3)$ \\
\hline 1. & 2010 & 0,3130 \\
2. & 2011 & 0,3032 \\
3. & 2012 & 0,2922 \\
3. & 2013 & 0,2790 \\
4. & 2014 & 0,2638 \\
\hline
\end{tabular}

Sumber: Hasil Analisis Indeks Williamson (data diolah)

Angka indeks williamson semakin kecil atau mendekati nol menunjukan ketimpangan yang semakin kecil dengan kata lain makin merata, dan bila semakin jauh dari nol menunjukan ketimpangan yang semakin melebar. Hal ini berarti tidak membuktikan bahwa semakin banyak pembangunan yang dilakukan maka tingkat kemungkinan ketimpangan yang akan terjadi semakin tinggi.

Tabel 6 di atas menjelaskan bahwa pada tahun 2010 angka ketimpangan Indeks Williamson sebesar 0,3130; pada tahun 2011 angka ketimpangan Indeks Williamson turun menjadi 0,3032 dan terus menurun pada tahun 2012 menjadi 0,2922. Tahun 2014 angka ketimpangan Indeks menurun menjadi 02638. Hal ini berarti secara rata-rata PDRB per kapita antar Kabupaten/Kota di Provinsi Maluku relatif merata, atau semakin kecil terjadi ketimpangan pembangunan dari tahun 2010 sampai tahun 2014.

\subsection{Hubungan Antara Indeks Williamson Dengan PDRB Per Kapita}

Hubungan antara Indeks Williamson dan PDRB per kapita dapat dilihat dari analsis korelasi pearson. Hasil korelasi dapat dilihat dari nilai signifikansinya. Pengolahan data statistik melalui korelasi pearson untuk mengetahui hubungan antara PDRB per kapita dengan Indeks Williamson, hasilnya sebesar -0,952 dengan nilai signifikansi 0,001 yang berarti adalah secara statistik adanya korelasi pearson dan hubungannya adalah negatif. 
Tabel 7. Hasil Analisis Korelasi Pearson

\begin{tabular}{|c|c|c|c|}
\hline & & $\begin{array}{c}\text { Indeks } \\
\text { Williamson } \\
\text { Provinsi } \\
\text { Maluku }\end{array}$ & $\begin{array}{c}\text { PDRB Per } \\
\text { Kapita } \\
\text { Provinsi } \\
\text { Maluku } \\
\end{array}$ \\
\hline \multirow{5}{*}{$\begin{array}{l}\text { Indeks Williamson } \\
\text { Provinsi Waluku }\end{array}$} & Pearson Correlation & 1 & $-.952 "$ \\
\hline & Sig. (2-tailed) & & .001 \\
\hline & $\begin{array}{l}\text { Sum of Squares and } \\
\text { Cross-products }\end{array}$ & .006 & -.635 \\
\hline & Covariance & .001 & -.106 \\
\hline & N & 7 & 7 \\
\hline \multirow{5}{*}{$\begin{array}{l}\text { PDRB Per Kapita Provinsi } \\
\text { Maluku }\end{array}$} & Pearson Correlation & $-.952^{\prime \prime}$ & 1 \\
\hline & Sig. (2-tailed) & .001 & \\
\hline & $\begin{array}{l}\text { Sum of Squares and } \\
\text { Cross-products }\end{array}$ & -.635 & 70.920 \\
\hline & Covariance & -.106 & 11.820 \\
\hline & $\mathbf{N}$ & 7 & 7 \\
\hline
\end{tabular}

Sumber: Hasil Analisis Korelasi Pearson (data diolah)

\subsection{Hipotesis Kuznets "U-terbalik" di Provinsi Maluku}

Hipotesis Kuznets dapat dibuktikan dengan membuat grafik Indeks Williamson dengan PDRB Perkapitadengan data yang dimulai sejak tahun 2008.

Tabel 8. Indeks Williamson dan PDRB Per Kapita Provinsi Maluku (PDRB seri 2010 = 100) Tahun 2008 - 2014

\begin{tabular}{cccc}
\hline No & Tahun & Indeks Williamson & PDRB Per Kapita (Juta Rp) \\
\hline$(1)$ & $(2)$ & $(3)$ & $(4)$ \\
\hline 1. & 2008 & 0,3598 & 9,93 \\
2. & 2009 & 0,3310 & 10,77 \\
3. & 2010 & 0,3130 & 11,95 \\
4. & 0,3032 & 13,60 \\
5. & 2011 & 0,2922 & 15,42 \\
6. & 2012 & 0,2790 & 17,09 \\
7. & $2013^{*}$ & 0,2638 & 19,15 \\
\hline
\end{tabular}

Sumber: Hasil Analisis Indeks Williamson (data diolah)

Untuk menguji Hipotesis Kuznet dapat digunakan Regresi Non Linier untuk itu digunakan analisis Regresion Curve Estimation. Sehingga akan diperoleh suatu kurva yang membentuk garis lengkung menurun $(\beta 1<0)$ atau menaik $(\beta 2>0)$. Tabel 9 merupakan hasil analysis Regresion Curve Estimation.

Tabel 9. Hubungan Angka Indeks Williamson dengan PDRB Per Kapita Provinsi Maluku

Tahun 2008 - 2014

\begin{tabular}{|c|c|c|c|c|c|}
\hline & \multicolumn{2}{|c|}{ Unstandardized Coefficients } & \multirow{2}{*}{$\begin{array}{c}\begin{array}{c}\text { Standardized } \\
\text { Coefficients }\end{array} \\
\text { Beta } \\
\end{array}$} & \multirow[b]{2}{*}{$\mathrm{t}$} & \multirow[b]{2}{*}{ Siq. } \\
\hline & $\mathrm{B}$ & Std. Error & & & \\
\hline $\begin{array}{l}\text { PDRB Per Kapita Provinsi } \\
\text { Maluku }\end{array}$ & -.029 & .013 & -3.080 & -2.195 & .093 \\
\hline $\begin{array}{l}\text { PDRB Per Kapita Provinsi } \\
\text { Maluku }{ }_{2}\end{array}$ & .001 & .000 & 2.135 & 1.522 & .203 \\
\hline (Constant) & .568 & .091 & & 6.207 & .003 \\
\hline
\end{tabular}

Sumber: Hasil Analisis Korelasi Pearson (data diolah) 
Hubungan Angka Indeks Williamson dengan PDRB Per Kapita Provinsi Maluku diperoleh konstanta sebesar $0,568 \beta_{1}$ sebesar $-0,029$ dan nilai $\beta_{2}$ sebesar 0,001 . Nilai koefisien $\beta_{2}$ bernilai positif $(\beta>0)$ menunjukan akan diperoleh suatu kurva yang membentuk garis melengkung menanjak. Nilai signifikan sebesar 0,093 secara statistik model Regresion Curve Estimation dapatditerima sehingga persamaan Regresion Curve Estimation adalah: $I W=0,568-0,029 Y+0,001 Y^{2}$.

Pembuktian kurva U-terbalik dilakukan dengan membuat kurva hubungan antara Indeks Williamson dengan PDRB per kapita untuk itu digunakan Regresion Curve Estimation seperti pada gambar 1.

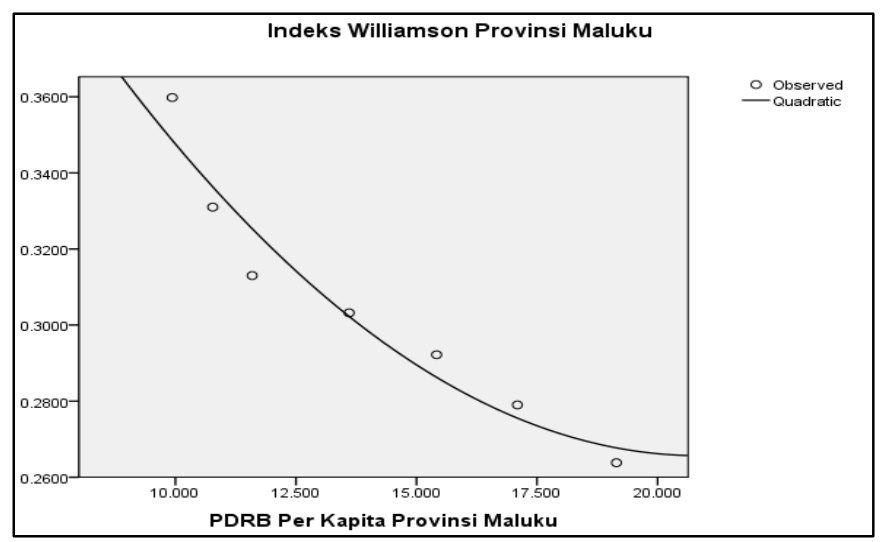

Gambar 1. Grafik hubungan antara Indeks Williamson dan PDRB perkapita Provinsi Maluku, Tahun 2008 - 2014

Gambar 1 merupakan hubungan antara PDRB perkapita dan indeks ketimpangan. Gambar tersebut tidak menunjukan kurva berbetuk U-terbalik, ini berarti teori Kuznets tentang kurva U-terbalik tidak berlaku di Provinsi Maluku. Ini membuktikan bahwa pada awal terjadinya pertumbuhan ekonomi disertai dengan ketimpangan yang menurun pada masa berikutnya ketimpangan ini akan semakin meningkat pada masa berikutnya.

\section{Kesimpulan}

Pembahasan hasil penelitian secara ringkas dapat disimpulkan sebagai berikut:

a. Dari hasil Tipologi Klassen, Provinsi Maluku dapat dibagi menjadi empat klasifikasi. Daerah yang pertama yakni Daerah Maju dan Tumbuh Cepat terdiri dari empat kabupaten/kota yakni Kota Ambon, Kota Tual, Kabupaten Maluku Tenggara dan Kabupaten Kepulauan Aru. Daerah yang kedua yakni Daerah Berkembang Cepat Tapi Tidak Maju terdiri dari Kabupaten Maluku Tenggara Barat dan Kabupaten Maluku Barat Daya. Daerah yang ketiga adalah Daerah Maju Tapi Tertekan yakni Kabupaten Seram Bagian Timur. Daerah keempat merupakan Daerah Relatif Tertinggal yang terdiri dari Kabupaten Maluku Tengah, Kabupaten Seram Bagian Timur, Kabupaten Buru dan Kabupaten Buru Selatan.

b. Selama periode pengamatan tahun 2010-2014 angka ketimpangan dihitung dengan Indeks Williamson mengalami penurunan dari tahun ke tahun. Hal ini dapat dikatakan ketimpangan pembangunan di Provinsi Maluku mengalami penurunan dari tahun ke tahun.

c. Hipotesis Kuznets tentang kurva U-terbalik di Provinsi Maluku tidak berlaku pada periode penelitian (2008-2014). 


\section{Daftar Pustaka}

[1] Badan Pusat Statistik Provinsi Maluku, Maluku dalam Angka 2009, Ambon, 2010.

[2] Badan Pusat Statistik Provinsi Maluku, Maluku dalam Angka 2010, Ambon, 2011.

[3] Badan Pusat Statistik Provinsi Maluku, Maluku dalam Angka 2011, Ambon, 2012.

[4] Badan Pusat Statistik Provinsi Maluku, Maluku dalam Angka 2012, Ambon, 2013.

[5] Badan Pusat Statistik Provinsi Maluku, Maluku dalam Angka 2013, Ambon, 2014.

[6] Badan Pusat Statistik Provinsi Maluku, Produk Domestik Regional Bruto Provinsi Maluku menurut Lapangan Usaha 2010-2014, Ambon, 2015.

[7] M. Kuncoro, Otonomi Pembangunan Daerah, Jakarta: Erlangga, 2004.

[8] P. D. K. Sari, "Pertumbuhan Ekonomi dan Ketimpangan antar Kecamatan di Kabupaten Buleleng," Jurnal Ekonomi Pembangunan Universitas Udayana, 2013.

[9] J. Tipka, “Analisis Ketimpangan Pembangunan antar Kecamatan di Kota Ambon,” Barekeng, vol. 8, no. 2, pp. 41-45, 2014. 